\title{
TINGKAT PEMANFAATAN IKAN LAYANG (Decapterus russelli dan Decapterus macrosoma) DARI PERAIRAN ZONA EKONOMI EKSLUSIF LAUT CINA SELATAN
}

\author{
Tuti Hariati ${ }^{1)}$, Wudianto ${ }^{2)}$, dan Subagja ${ }^{3)}$ \\ 1)nPeneliti pada Balai Riset Perikanan Laut, Muara Baru-Jakarta \\ 2) Peneliti pada Pusat Riset Perikanan Tangkap, Ancol-Jakarta \\ 3) Peneliti pada Balai Riset Perikanan Perairan Umum, Mariana-Palembang \\ Teregristrasi I tanggal: 8 Agustus 2008; Diterima setelah perbaikan tanggal: 25 September 2008; \\ Disetujui terbit tanggal: 14 Oktober 2008
}

\begin{abstract}
ABSTRAK
Untuk memperoleh dugaan tingkat pemanfaatan (E) dari 2 spesies ikan layang (Decapterus russelli dan Decapterus macrosoma), telah dilakukan analisis terhadap 12 set data bulanan frekuensi panjang ke-2 spesies selama tahun 2003, 2004, dan 2005 dari 2 daerah penangkapan pukat cincin di perairan Laut Cina Selatan (perairan Natuna dan Anambas), yang diperoleh dari 3 lokasi pendaratan kapal pukat cincin. Analisis dimulai dengan pendugaan parameter pertumbuhan dan parameter kematian. Seluruh analisis dilakukan dengan paket program FiSAT, dengan pilihan model progression analysis (metode Bhatacharya dan Gulland \& Holt Plot) dalam pendugaan parameter pertumbuhan. Hasil analisis menunjukkan, kisaran E tiap tahun untuk Decapterus russelli di perairan Natuna 0,65 sampai dengan 0,67 dan di perairan Anambas 0,52 sampai dengan 0,54; untuk Decapterus macrosoma di perairan Natuna 0,65 sampai dengan 0,66 dan di perairan Anambas 0,60 sampai dengan 0,62. Tingkat pemanfaatan ke-2 spesies ikan layang (Decapterus russelli dan Decapterus macrosoma) di perairan Laut Cina Selatan Indonesia selama tahun 2003 sampai dengan 2005 sudah tinggi sehingga disarankan tidak dilakukan penambahan jumlah kapal pukat cincin yang diizinkan beroperasi di perairan Laut Cina Selatan Indonesia.
\end{abstract}

KATAKUNCl: $\quad$ ikan layang, Laut Cina Selatan, tingkat pemanfaatan

ABSTRACT: Exploitation rate of scads (Decapterus Russelli and Decapterus Macrosoma) from the waters of South China Sea. By: Tuti Hariati, Wudianto, and Subagja

To obtain the estimation of exploitation rates (E) of the two species of scads (Decapterus russelli and Decapterus macrosoma), the analysis on 12 sets of monthly length frequencies data of both species during years 2003, 2004, and 2005 from 2 fishing grounds in the South China Sea was conducted. The analysis is started by estimating growth and mortality parameters. Analysis was done using the FISAT package program, with model progression analysis (Bhatacharya dan Gulland \& Holt Plot methods). The results show that the exploitation rate of Decapterus russelli each year in the Natuna waters were 0.65 to 0.67, and in the Anambas waters were 0.52 to 0.54; for Decapterus macrosoma in the Natuna waters were 0.65 to 0.66 while in Anambas waters 0.60 to 0.62 . The Evalues of both species of scad in the South China Sea of Indonesia during years 2003 to 2005 have already high. Therefore, it is suggested not to allow the addision the number of purse seiners operated in the South China Sea of Indonesia.

\section{KEYWORDS: $\quad$ scads, South China Sea, exploitation rate}

\section{PENDAHULUAN}

Keseluruhan dari perairan Laut Cina Selatan merupakan bagian-bagian dari sedikitnya 7 negara di sekeliling yaitu Vietnam, Phillipina, Kamboja, Thailand, Malaysia, Brunei Darussalam, dan Indonesia. Laut Cina Selatan merupakan salah satu daerah penangkapan yang penting terutama bagi para nelayan dari 7 negara tersebut. Laut Cina Selatan wilayah Indonesia merupakan paparan Sunda bagian barat dengan kedalaman rata-rata $70 \mathrm{~m}$. Di atas dasar perairan yang pada umumnya rata, terjadi stratifikasi massa air musiman (Wyrtki, 1961). Luas perairan Laut
Cina Selatan Indonesia sekitar $595 \mathrm{~km}^{2}$ (South China Sea, 1979; Cholik et al., 1995).

Pemanfaatan sumber daya ikan pelagis kecil, salah satu sumber daya ikan yang dominan di Laut Cina Selatan, telah berlangsung sejak tahun 1970-an di perairan pantai barat Kalimantan, menggunakan jaring insang dengan lama di laut 1 hari per trip. Penangkapan dengan pukat cincin asal Pontianak dan Pemangkat dimulai pada tahun 1986 dan 1990, dengan jumlah kapal ukuran medium 30 dan 4 unit. Pada tiap tahun selama musim peralihan 1 sampai dengan musim timur (bulan Maret sampai dengan Juli) sejumlah kapal 
pukat cincin ukuran besar asal Pekalongan melakukan penangkapan ikan pelagis kecil di Laut Cina Selatan (Sadhotomo \& Potier, 1995).

Perikanan pukat cincin di Laut Cina Selatan semakin berkembang antara lain dengan beroperasi kapal dari Selat Malaka yang andon di Batam dan armada pukat cincin mini dan jaring lingkar asal Indramayu yang berpangkalan di Palembang. Peralatan yang dibawa semakin canggih seperti fish finder, GPS, dan lampu sebagai alat bantu penangkapan. Hasil tangkapan didominansi oleh ikan layang (Decapterus russelli dan Decapterus macrosoma) dan selar bentong (Selaroides crumenopthalmus). Daerah penangkapan semakin jauh dari pangkalan, mencapai zona ekonomi ekslusif Indonesia di sekitar Kepulauan Natuna dan Kepulauan Anambas. Dari survei akustik tahun 1985 di ke-2 daerah penangkapan tersebut, diduga potensi ikan pelagis masing-masing 150.000 dan 183.000 (Badrudin, 1986). Dua spesies ikan layang (Decapterus russelli dan Decapterus macrosoma) mendominansi hasil tangkapan 3 armada pukat cincin yang beroperasi di perairan Laut Cina Selatan khususnya di perairan lepas pantai sekitar Kepulauan Natuna dan Anambas yang berbasis di Palembang, Pemangkat, dan Pekalongan. Selama periode tahun 2003 sampai dengan 2005, kontribusi ke-2 spesies tersebut (Decapterus russelli dan Decapterus macrosoma) di dalam hasil tangkapan pukat cincin masing-masing 63 dan $23 \%$ yang berbasis di Palembang, 27 dan 24\% di Pemangkat, dan 34 dan $32 \%$ di Pekalongan. Hasil tangkapan Decapterus russelli tiap tahun dari perairan Natuna dan Anambas dari 3 pendaratan tiap tahun dalam periode tahun 2003 sampai dengan 2005 mencapai rata-rata 3.032,3 ton, sedangkan hasil tangkapan Decapterus macrosoma rata-rata $2.543,8$ ton.

Analisis frekuensi panjang 2 spesies ikan layang (Decapterus russelli dan Decapterus macrosoma) pada tahun 2003, 2004, dan 2005 dimaksudkan untuk memperoleh dugaan tingkat pemanfaatan masingmasing spesies yang tertangkap di perairan Natuna dan Anambas.

\section{BAHAN DAN METODE}

\section{Waktu dan Tempat}

Pengumpulan data sebaran frekuensi panjang ikan layang biasa (Decapterus russelli) dan layang deles (Decapterus macrosoma) dilaksanakan pada tiap bulan pada periode bulan Maret 2003 sampai dengan Desember 2005 di 3 pendaratan yaitu di Pemangkat mewakili hasil tangkapan pukat cincin di perairan
Natuna, Palembang mewakili hasil tangkapan dari perairan Anambas. Di Pekalongan pengumpulan data tersebut hanya dilakukan antara bulan Maret dan Agustus yaitu saat armada pukat cincin melakukan penangkapan di Laut Cina Selatan.

\section{Prosedur Pengumpulan Data}

Pengambilan contoh sesuai dengan prosedur standar operasional dalam pengkajian stok yang diprakarsai oleh SEAFDEC (Standart Operational Procedure- Mat Isa et al., 2004) berdasarkan pada prinsip prosedur dalam Sparre \& Venema (1999) dengan rincian sebagai berikut.

Pada tiap lokasi, 1 keranjang ikan (40 kg) hasil tangkapan diambil secara acak dari kapal contoh 2 kali setiap minggu dari sebelum sampai dengan sesudah periode bulan gelap ( 6 kali per bulan). Beberapa jenis ikan terutama pelagis kecil disortir menurut spesies, lalu ditimbang. Panjang total (total length) ke-2 spesies ikan layang (Decapterus russelli dan Decapterus macrosoma) contoh diukur menggunakan kertas ukur khusus sekitar 50 ekor per spesies. Dalam 1 bulan jumlah ikan yang diukur tiap spesies ikan layang (Decapterus russelli dan Decapterus macrosoma) sekitar 300 ekor. Data frekuensi panjang setiap contoh disusun menurut nilai tengah total length dengan kisaran $0,5 \mathrm{~cm}$.

Nama kapal, tanggal pengukuran, dan komposisi jenis ikan dicatat dalam kertas ukur. Total hasil tangkapan per jenis ikan dari kapal contoh terutama ikan layang (Decapterus russelli dan Decapterus macrosoma) (campuran 2 spesies) dicatat dari nakhoda. Hasil tangkapan ikan layang biasa $\left(\mathrm{W}_{\mathrm{LB}}\right)$ (Decapterus russelli) dan layang deles $\left(\mathrm{W}_{\mathrm{LD}}^{\mathrm{LB}}\right)$ (Decapterus macrosoma) per kapal diduga berdasarkan pada perbandingan bobot contoh tiap spesies ikan layang (Decapterus russelli dan Decapterus macrosoma) ( $\mathrm{w}_{\mathrm{lb}}$ dan $\left.\mathrm{w}_{\mathrm{ld}}\right)$.

Terhadap data frekuensi panjang (length frequency) tiap spesies ikan layang (Decapterus russelli dan Decapterus macrosoma) dari 1 kapal contoh dilakukan pembobotan (rise) terhadap hasil tangkapan tiap spesies ikan layang (Decapterus russelli dan Decapterus macrosoma) dalam kapal tersebut dengan rising factor $(\mathrm{rf})=\mathrm{W}_{\mathrm{LB}} / \mathrm{w}_{\mathrm{lbi}}$ untuk ikan layang biasa (Decapterus russelli), $\mathrm{W}_{\mathrm{LDi}} / \mathrm{w}_{\text {ldi }}$ untuk ikan layang deles (Decapterus macrosoma). Seluruh data length frequency tiap spesies dari tiap kapal dalam 1 bulan digabung ( $p o o l e d$ ) sehingga hanya ada 1 contoh data length frequency setiap spesies pada tiap bulan. Data length frequency (pooled) bulanan tersebut di rise lagi terhadap hasil tangkapan bulanan $\left(\mathrm{W}_{\mathrm{M}}\right)$ dengan faktor 
$(\mathrm{rf})=\mathrm{W}_{\mathrm{M}} / \mathrm{WLB}$, kemudian disusun menurut tahun (annual basis), sehingga diperoleh 12 set data length frequency 2 spesies dari 2 daerah penangkapan pada tahun 2003, 2004, dan 2005.

\section{Analisis Data}

Untuk memperoleh dugaan parameter pertumbuhan ( $\mathrm{L}$, dan $\mathrm{K}$ ), dan parameter kematian ikan, digunakan paket program FiSAT Gayanilo \& Pauly (1997) pada model progression analysis.

\section{a. Pertumbuhan}

Data frekuensi panjang bulanan dianalisis dengan Bhatacharya untuk memperoleh nilai-nilai tengah panjang ikan yang mewakili tiap kohor pada tiap-tiap bulan. Garis-garis pertumbuhan tiap kohor dirunut dengan menghubungkan nilai-nilai tengah ikan dari yang terkecil sampai dengan yang terbesar dari suatu kohor dengan analisis lingking of mean. Nilai-nilai tengah terpilih dengan laju pertumbuhan (cm per hari) yang dihasilkan (growth increment data) dianalisis (regresi) dengan plot Gulland \& Holt, untuk memperoleh dugaan $\mathrm{L}_{00}=(-\mathrm{a} / \mathrm{b})$ dan $\mathrm{K}=(-\mathrm{b})$.

\section{b. Kematian}

Kematian total $(Z)$ diperoleh dari analisis length converted catch curve (kurva penangkapan yang dikonversikan ke panjang):

$\operatorname{Ln}\left(\mathrm{C}\left(\mathrm{L}_{1}, \mathrm{~L}_{2} 2\right) / \mathrm{dt}\left(\mathrm{L}_{1}, \mathrm{~L}_{2}\right)\right)=\mathrm{C}-\mathrm{Z}^{*}\left(\mathrm{t}^{*}\left(\left(\mathrm{~L}_{1}+\mathrm{L}_{2}\right) / 2\right) \ldots \ldots \ldots . .(1\right.$

Dalam analisis ini, digunakan data frekuensi panjang dan nilai-nilai $\mathrm{L}_{\text {oo }}$ \& $\mathrm{K}$ sebagai input. Setelah kurva terbentuk dipilih data panjang ikan yang terkena eksploitasi, untuk dianalisis (regresi) menghasilkan $Z$ (-b). Kematian alami (M) diduga dengan rumus empiris Pauly:

$M=\operatorname{Exp}\left(-0,0152-0,279^{*} L_{n} L_{o o}+0,6543^{*} L_{n} K+0,463^{*} L_{n} \top \ldots\right.$

di mana:

$\mathrm{T}$ = suhu perairan dari survei laut di daerah penangkapan $29^{\circ} \mathrm{C}$ dimasukkan sebagai input

Ikan layang (Decapterus russelli dan Decapterus macrosoma) bersifat menggerombol sehingga nilai $\mathrm{M}$ yang diperoleh dikoreksi menjadi $20 \%$ lebih rendah yaitu:

$M=0,8 \operatorname{Exp}\left(-0,0152-0,279^{*} L_{n} L_{o 0}+0,6543^{*} L_{n}\right.$ $K+0,463^{*} L_{n} T$ (Sparre \& Venema, 1999) (3
Kematian karena penangkapan $(F)$ diperoleh dari nilai $Z$ dikurangi $M$, sedangkan dugaan tingkat pemanfaatan (E) dari $F$ dibagi $Z$.

\section{HASIL DAN BAHASAN}

\section{Analisis Data Decapterus Russelli dari Perairan Natuna Tahun 2003}

\section{a. Data Frekuensi Panjang}

Data frekuensi panjang ikan layang (Decapterus russelli dan Decapterus macrosoma) bulanan yang tercantum dalam Tabel 1 berasal dari hasil pengukuran di tiap kapal contoh (rata-rata 6 kali tiap bulan) yang telah di rised terhadap total hasil tangkapan Decapterus russelliper kapal contoh. Setelah dipooled setiap bulan kemudian dirised ke-2 kali terhadap produksi bulanan spesies tersebut di tiap lokasi pendaratan.

Data frekuensi panjang pada Tabel 1, merupakan gabungan data frekuensi panjang dari Pekalongan dan Pemangkat tahun 2003, dan telah siap dianalisis. Dalam riset ini telah diperoleh 12 set data serupa, dari 2 spesies ikan layang (Decapterus russelli dan Decapterus macrosoma) dari 2 daerah penangkapan (perairan Natuna dan Anambas) selama tahun 2003, 2004, dan 2005.

\section{b. Metode Bhattacharya}

Ke-12 set data frekuensi panjang dianalisis dengan Bhattacharya untuk memisahkan kohor-kohor yang terdapat dalam frekuensi panjang tiap-tiap bulan. Sebagai contoh set data Decapterus russelli dari perairan Natuna tahun 2003, setelah dianalisis, diperoleh 36 nilai panjang rata-rata dan standar deviasi yang mewakili tiap kohor (Tabel 2a).

Dalam proses selanjutnya (Linking of the mean), 8 nilai tengah antara lain (huruf tebal) dipilih dan dirunut sebagai salah satu kohor yang digunakan untuk menduga nilai-nilai $\mathrm{L}_{\circ 0}$ dan $\mathrm{K}$ (Tabel 2).

Dalam Gambar 1 nilai-tengah panjang ikan diplot tiap bulan sebagai titik-titik (kuning dan biru). Titiktitik biru yang dihubungkan dengan garis biru adalah nilai-nilai tengah panjang yang ditebalkan. $\mathrm{Ke}-7$ nilai tengah yang terpilih, dianalisis dengan Plot Gulland \& Holt (1959) dalam Sparre \& Venema (1999) untuk pendugaan parameter pertumbuhan. 
Tabel 1. $\quad$ Frekuensi panjang ikan layang (Decapterus russelli dan Decapterus macrosoma) bulanan yang tertangkap dengan pukat cincin di perairan sekitar Natuna, tahun 2003

Table 1. Monthly length frequency of scad (Decapterus russelli and Decapterus macrosoma) caught by purse seine in the waters around Natuna Islands during year 2003

\begin{tabular}{|c|c|c|c|c|c|c|c|c|c|c|}
\hline $\begin{array}{l}\text { Midlength } \\
\text { (cm) }\end{array}$ & M & A & M & $\mathbf{J}$ & $\mathbf{J}$ & A & $\mathbf{S}$ & 0 & $\mathbf{N}$ & D \\
\hline 9,75 & 0 & 0 & 5.601 & 0 & 114.897 & 0 & 0 & 0 & 0 & 0 \\
\hline 10,25 & 0 & 0 & 5.601 & 0 & 4.534 .410 & 0 & 0 & 0 & 0 & 0 \\
\hline 10,75 & 0 & 0 & 23.454 & 0 & 13.858 .958 & 0 & 0 & 0 & 1.030 & 0 \\
\hline 11,25 & 0 & 0 & 17.928 & 0 & 17.195 .833 & 0 & 0 & 0 & 0 & 0 \\
\hline 11,75 & 0 & 0 & 61.588 & 299.235 & 24.240 .209 & 13.200 & 0 & 8.635 & 0 & 0 \\
\hline 12,25 & 0 & 15.401 & 74.759 & 0 & 18.593 .508 & 17.609 & 0 & 11.513 & 0 & 0 \\
\hline 12,75 & 1.922 .520 & 7.701 & 110.699 & 0 & 7.044 .376 & 16.139 & 0 & 14.898 & 26.575 & 0 \\
\hline 13,25 & 1.922 .520 & 31.727 & 38.988 & 598.469 & 6.137 .920 & 28.864 & 0 & 28.206 & 0 & 100 \\
\hline 13,75 & 3.845 .040 & 132.567 & 88.502 & 0 & 9.110 .450 & 45.487 & 0 & 20.790 & 0 & 12.124 \\
\hline 14,25 & 1.922 .520 & 123.589 & 296.788 & 341.436 & 13.791 .846 & 131.855 & 0 & 89.218 & 0 & 25.098 \\
\hline 14,75 & 0 & 194.548 & 427.363 & 2.265 .359 & 4.315 .479 & 147.261 & 0 & 209.318 & 27.586 & 47.874 \\
\hline 15,25 & 5.530 & 225.440 & 638.089 & 2.094 .642 & 14.621 .721 & 736.910 & 0 & 361.435 & 106.298 & 61.278 \\
\hline 15,75 & 11.060 & 284.192 & 781.268 & 2.863 .828 & 1.889 .687 & 690.923 & 0 & 396.120 & 406.133 & 57.530 \\
\hline 16,25 & 1.950 .171 & 449.574 & 1.382 .111 & 3.890 .049 & 6.254 .664 & 613.567 & 0 & 364.550 & 317.412 & 56.886 \\
\hline 16,75 & 5.789 .681 & 218.406 & 831.161 & 2.094 .642 & 3.429 .081 & 1.199 .609 & 0 & 338.611 & 237.241 & 57.098 \\
\hline 17,25 & 21.191 .668 & 311.678 & 1.075 .476 & 897.704 & 2.396.715 & 1.149 .859 & 0 & 244.231 & 218.775 & 47.098 \\
\hline 17,75 & 23.086 .538 & 430.520 & 1.091 .508 & 469.952 & 1.025 .598 & 680.012 & 0 & 222.006 & 267.510 & 31.502 \\
\hline 18,25 & 23.116 .880 & 331.668 & 1.044 .280 & 0 & 2.438 .110 & 534.613 & 0 & 134.832 & 263.182 & 13.224 \\
\hline 18,75 & 19.266 .015 & 617.064 & 700.317 & 0 & 1.080 .955 & 270.945 & 0 & 49.000 & 136.550 & 0 \\
\hline 19,25 & 93.423 & 479.874 & 380.670 & 0 & 54.647 & 104.319 & 0 & 3.387 & 131.995 & 0 \\
\hline 19,75 & 76.685 & 425.691 & 206.449 & 0 & 27.617 & 55.167 & 0 & 0 & 93.323 & 0 \\
\hline 20,25 & 9.639 .957 & 237.460 & 207.777 & 0 & 32.794 & 9.222 & 0 & 0 & 90.281 & 0 \\
\hline 20,75 & 3.855 .806 & 186.556 & 43.586 & 0 & 14.071 & 0 & 0 & 0 & 33.117 & 0 \\
\hline 21,25 & 0 & 90.919 & 23.260 & 0 & 7.036 & 0 & 0 & 0 & 9.037 & 0 \\
\hline 21,75 & 5.530 & 23.324 & 0 & 0 & 7.731 & 0 & 0 & 0 & 0 & 0 \\
\hline 22,25 & 2.691 & 15.767 & 8.964 & 0 & 0 & 0 & 0 & 0 & 0 & 0 \\
\hline 22,75 & 11.060 & 15.767 & 0 & 0 & 1.933 & 0 & 0 & 0 & 0 & 0 \\
\hline 23,25 & 2.691 & 0 & 0 & 0 & 1.933 & 0 & 0 & 0 & 0 & 0 \\
\hline 23,75 & 0 & 0 & 0 & 0 & 0 & 0 & 0 & 0 & 0 & 0 \\
\hline 24,25 & 0 & 0 & 0 & 0 & 0 & 0 & 0 & 0 & 0 & 0 \\
\hline 24,75 & 0 & 0 & 0 & 0 & 0 & 0 & 0 & 0 & 0 & 0 \\
\hline 25,25 & 0 & 0 & 0 & 0 & 0 & 0 & 0 & 0 & 0 & 0 \\
\hline
\end{tabular}

\section{c. Metode Plot Gulland \& Holt}

Ke-7 nilai-nilai tengah yang dipilih, dianalisis secara mark and recapture sehingga diperoleh 6 nilai tengah beserta laju pertumbuhan per hari (Tabel 2b).

Plot nilai tengah terhadap laju pertumbuhan menghasilkan $\mathrm{L}_{\mathrm{oo}}=-\mathrm{a} / \mathrm{b}$ dan $\mathrm{K}$ yaitu $-\mathrm{b}$ masing-masing $\mathrm{L}_{\text {oo }}=25,84 \mathrm{~cm}$ TL dan $\mathrm{K}=1,2\left(\mathrm{R}^{2}=0,7162\right)$.

\section{d. Metode Kurva Hasil Tangkapan untuk Menghitung Parameter Kematian}

Setelah membuka file frekuensi panjang Decapterus russelli tahun 2003 dan memasukkan nilai-nilai $\mathrm{L}_{\mathrm{oo}}$ dan $\mathrm{K}$ hasil analisis, dilakukan pilihan untuk menentukan bagian dari kurva hasil tangkapan yang terkena eksploitasi. Maka diperoleh nilai $Z=4,92$.
Setelah suhu perairan diinputkan, nilai M keluar (2.138). Mengingat ikan layang (Decapterus russelli dan Decapterus macrosoma) bertabiat suka menggerombol, maka nilai M tersebut dikoreksi $20 \%$ (Sparre \& Venema, 1999), sehingga nilai M menjadi $80 \%$ lebih rendah $(1,71)$. Setelah memasukkan nilai $M$ yang baru (1.710), diperoleh nilai-nilai $F(3,21)$ dan $\mathrm{E}=0,65$ (Gambar 2).

\section{Parameter Pertumbuhan $\left(\mathrm{L}_{\mathrm{oo}}\right.$ dan $\mathrm{K}$ ) Ikan Layang (Decapterus russelli dan Decapterus macrosoma)}

\section{a. Di perairan Natuna}

Nilai dugaan $\mathrm{L}_{\text {oo }}$ Decapterus russelli dan Decapterus macrosoma tiap tahun berfluktuasi antara 25 sampai dengan $28 \mathrm{~cm}$, dan cenderung turun pada tahun 2005, sedangkan nilai K tetap 1,2 (Tabel 3a). 
Tabel 2a. $\quad 36$ nilai tengah panjang ikan layang (Decapterus russelli dan Decapterus macrosoma) hasil analisis data frekuensi panjang tahun 2003 dengan metode Bhattacharya

Table 2a. $\quad 36$ values of mean length of scad (Decapterus russelli and Decapterus macrosoma) produced from the analysis of length frequency data year 2003 using Bhattacharya method

\begin{tabular}{cccccccccc}
\hline No. & $\begin{array}{c}\text { Bulan/ } \\
\text { Month }\end{array}$ & $\begin{array}{c}\text { Tahun/ } \\
\text { Year }\end{array}$ & $\begin{array}{c}\text { Nilai tengah/ } \\
\text { Mean length } \\
\mathbf{( c m )}\end{array}$ & $\begin{array}{c}\text { Standar deviasi/ } \\
\text { Standar deviation }\end{array}$ & No. & $\begin{array}{c}\text { Bulan/ } \\
\text { Month }\end{array}$ & $\begin{array}{c}\text { Tahun/ } \\
\text { Year }\end{array}$ & $\begin{array}{c}\text { Nilai tengah } \\
\text { Mean length } \\
\text { (cm) }\end{array}$ & $\begin{array}{c}\text { Standar } \\
\text { deviasi/ } \\
\text { Standar } \\
\text { deviation }\end{array}$ \\
\hline 1. & 3 & 2003 & 13,75 & 0,42 & 19. & 7 & 2003 & 16,55 & 0,57 \\
2. & 3 & 2003 & 17,67 & 0,47 & 20. & 7 & 2003 & 18,31 & 0,34 \\
3. & 3 & 2003 & 20,42 & 0,21 & 21. & 7 & 2003 & 19,98 & 0,76 \\
4. & 3 & 2003 & 22,75 & 0,30 & 22. & 8 & 2003 & 12,38 & 0,82 \\
5. & 4 & 2003 & 14,12 & 0,58 & 23. & 8 & 2003 & 14,56 & 0,49 \\
6. & 4 & 2003 & 15,95 & 0,84 & 24. & 8 & 2003 & 17,03 & 0,65 \\
7. & 4 & 2003 & 17,91 & 0,50 & 25. & 8 & 2003 & 18,63 & 0,38 \\
8. & 4 & 2003 & 20,31 & 0,67 & 26. & 8 & 2003 & 19,64 & 0,32 \\
9. & 4 & 2003 & 22,54 & 0,30 & 27. & 10 & 2003 & 13,34 & 0,51 \\
10. & 5 & 2003 & 10,92 & 0,38 & 28. & 10 & 2003 & 16,13 & 1,03 \\
11. & 5 & 2003 & 14,72 & 0,54 & 29. & 10 & 2003 & 17,96 & 0,48 \\
12. & 5 & 2003 & 16,23 & 0,66 & 30. & 10 & 2003 & 18,17 & 0,83 \\
13. & 5 & 2003 & 18,06 & 0,84 & 31. & 11 & 2003 & 16,01 & 0,56 \\
14. & 5 & 2003 & 20,20 & 0,31 & 32. & 11 & 2003 & 17,86 & 0,75 \\
15. & 6 & 2003 & 14,98 & 0,36 & 33. & 11 & 2003 & 19,72 & 0,70 \\
16. & 6 & 2003 & 16,22 & 0,63 & 34. & 12 & 2003 & 14,09 & 0,25 \\
17. & 7 & 2003 & 10,98 & 0,38 & 35. & 12 & 2003 & 15,40 & 0,87 \\
18. & 7 & 2003 & 14,13 & 0,40 & 36. & 12 & 2003 & 17.17 & 0,70 \\
\hline
\end{tabular}

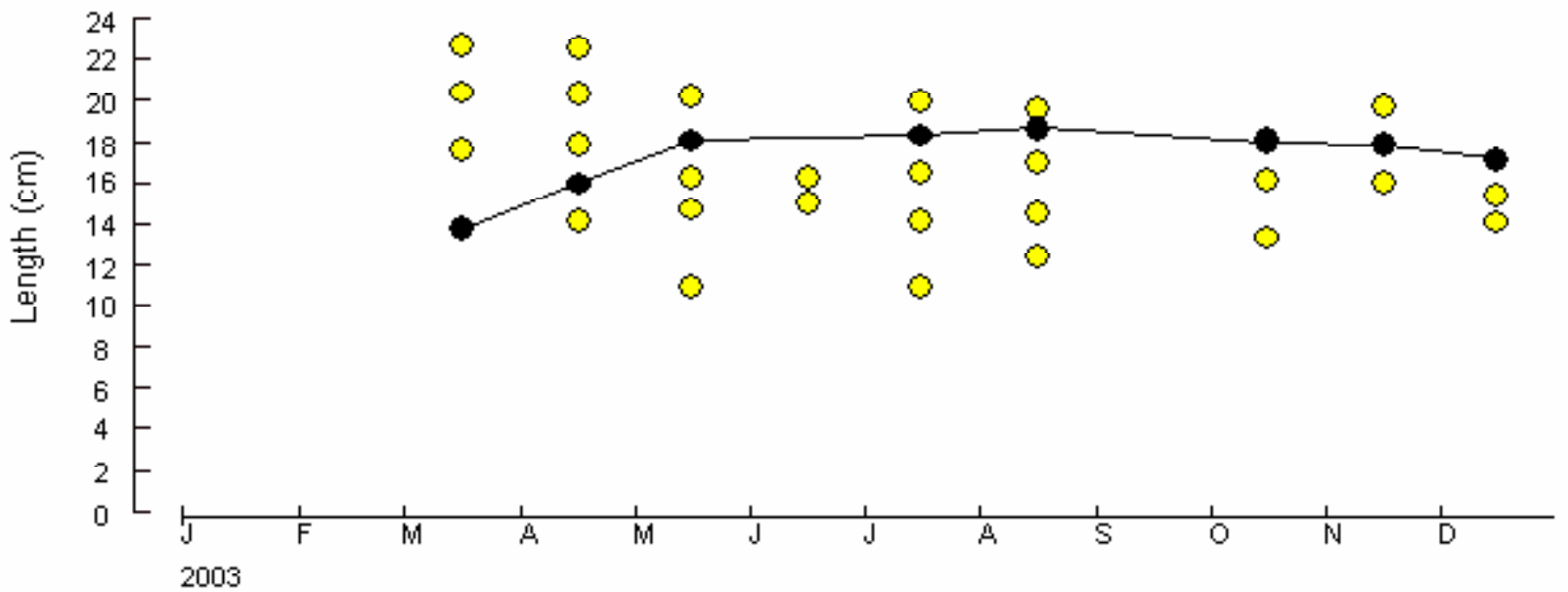

Gambar 1. Plot nilai tengah panjang ikan layang (Decapterus russellidan Decapterus macrosoma) dari perairan Natuna tiap bulan pada tahun 2003 dari Tabel 2.

Figure 1. Plot of mean length of scad (Decapterus russelli and Decapterus macrosoma) from the waters around Natuna Islands each month during year 2003 from Table 2.

Tabel 2b. Nilai tengah dan laju pertumbuhan ikan layang (Decapterus russelli dan Decapterus macrosoma) dari perairan Natuna tahun 2003, hasil analisis metode Plot Gulland \& Holt (1959)

Table 2b. Mean length and growth rate of scad (Decapterus russelli and Decapterus macrosoma) from the waters around Natuna Islands during year 2003, as the result of the analysis using Gulland \& Holt Plot method (1959)

\begin{tabular}{cccccc}
\hline No. & $\begin{array}{c}\text { Nilai tengah/ } \\
\text { Mean length }(\mathbf{c m})\end{array}$ & $\begin{array}{c}\text { dL per hari/ } \\
\boldsymbol{d} \text { L per day }\end{array}$ & No. & $\begin{array}{c}\text { Nilai tengah/ } \\
\text { Mean length }(\mathbf{c m})\end{array}$ & $\begin{array}{c}\text { dL per hari/ } \\
\boldsymbol{d L} \text { per day }\end{array}$ \\
\hline 1. & 14,85 & 0,071 & 4. & 17,91 & 0,003 \\
2. & 17,01 & 0,070 & 5. & 18,19 & 0,040 \\
3. & 17,52 & 0,023 & 6. & 18,30 & 0,011 \\
\hline
\end{tabular}


Dari hasil analisis data (frekuensi panjang) yang sama menggunakan metode Elefan (Hariati \& Pralampita, 2008), diperoleh nilai-nilai dugaan $\mathrm{L}_{\mathrm{oo}}$ yang relatif lebih rendah antara 24,1 dan $24,8 \mathrm{~cm}$ untuk Decapterus russelli dan 22,0 sampai dengan 23,6 cm untuk Decapterus macrosoma.

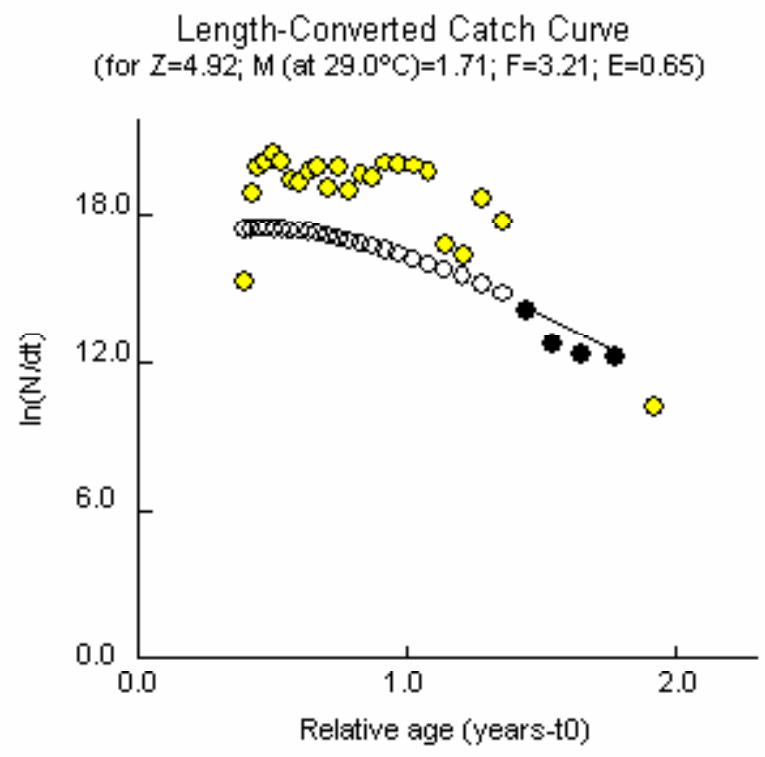

Gambar 2. Kurva hasil tangkapan dan nilai dugaan parameter kematian (Z, M, dan F) ikan layang

(Decapterus russelli dan Decapterus macrosoma) dari perairan sekitar Natuna, tahun 2003.

Figure 2. Catch curve and the values of mortality rates $(Z, M$, and $F$ ) of scad (Decapterus russelli and Decapterus macrosoma) from the waters around Natuna Islands, year 2003.

Tabel 3a. $\quad$ Nilai-nilai dugaan $\mathrm{L}_{\text {oo }}$ dan $\mathrm{K}$ ikan layang (Decapterus russelli dan Decapterus macrosoma) dari perairan Natuna, tahun 2003 sampai dengan 2005

Table 3a. $\quad$ Estimated values of $L_{o \circ}$ and K of scads (Decapterus russelli and Decapterus macrosoma) from the waters around Natuna Islands, years 2003 to 2005

\begin{tabular}{cccccc}
\hline Decapterus russelli & $\mathbf{L}_{\text {oo }}$ (cmTL) & $\mathbf{K}$ & Decapterus macrosoma & $\mathbf{L}_{\text {oo }}$ (cmTL) & $\mathbf{K}$ \\
\hline 2003 & 25,84 & 1,2 & 2003 & 25,60 & 1,2 \\
2004 & 26,06 & 1,2 & 2004 & 27,73 & 1,2 \\
2005 & 25,47 & 1,2 & 2005 & 25,32 & 1,2 \\
\hline
\end{tabular}

Tabel 3b. Nilai-nilai dugaan parameter pertumbuhan ikan layang (Decapterus russelli dan Decapterus macrosoma) di perairan Anambas, tahun 2003 sampai dengan 2005

Table 3b. Estimated values of growth parameters of scads (Decapterus russelli and Decapterus macrosoma) from the waters around Anambas Islands, years 2003 to 2005

\begin{tabular}{cccccc}
\hline Decapterus russelli & $\mathbf{L}_{\text {oo }}(\mathbf{c m T L})$ & $\mathbf{K}$ & Decapterus macrosoma & $\mathbf{L}_{\text {oo }}$ (cmTL) & $\mathbf{K}$ \\
\hline 2003 & 26,72 & 1,2 & 2003 & 26,75 & 1,2 \\
2004 & 26,58 & 1,2 & 2004 & 26,30 & 1,2 \\
2005 & 25,23 & 1,2 & 2005 & 25,15 & 1,2 \\
\hline
\end{tabular}

\section{b. Di perairan Anambas}

Pada tahun 2004 dan 2005, nilai-nilai dugaan $\mathrm{L}_{\text {oo }}$ Decapterus russelli dan Decapterus macrosoma di perairan Anambas cenderung turun dari tahun 2003, masing-masing dari 26,8 menjadi $25,2 \mathrm{~cm}$, sedangkan nilai $\mathrm{K}$ tetap (Tabel 3b).
Hasil analisis dengan metode Elefan (Hariati \& Pralampita, 2008) untuk Decapterus russellidari 24,4 $\mathrm{cm}$ turun menjadi $23,5 \mathrm{~cm}$, sedang untuk Decapterus macrosoma dari $26 \mathrm{~cm}$ menjadi $25,3 \mathrm{~cm}$.

Nilai-nilai dugaan $\mathrm{L}_{\text {oo }}$ dari Decapterus russelli dari ke-2 daerah penangkapan di Laut Cina Selatan tersebut berkisar antara 25 sampai dengan $27 \mathrm{~cm}$ 
sedangkan Decapterus macrosoma berkisar antara 25 sampai dengan $28 \mathrm{~cm}$. Nilai $\mathrm{K}$ masing-masing spesies selama periode tahun 2003 sampai dengan 2005 diduga konstan (1,2). Atmadja (1998), mengatakan bahwa metode Elefan 1 diperoleh nilai $\mathrm{L}_{\text {oo }}$ untuk Decapterus russelli $26,48 \mathrm{~cm}$ dan $\mathrm{K} 1,04$; sedang untuk Decapterus macrosoma $\mathrm{L}_{\mathrm{oo}} 26,17 \mathrm{~cm}$ dan K 0,93. Di Laut Cina Selatan perairan Manila pada periode tahun 2003 sampai dengan 2005, dengan metode Elefan telah diperoleh nilai $\mathrm{L}_{\mathrm{oo}}$ dan $\mathrm{K}$ masingmasing 34,72 cm dan 0,21 (Ramiscal et al., 2007), diduga karena panjang maksimum yang diperoleh di perairan Manila lebih tinggi. Di perairan utara Jawa, Widodo (1988) untuk Decapterus russelli mendapatkan nilai L, 30,2 cm FL dan K 0,9, ketika perikanan pukat cincin di perairan tersebut mulai berkembang ke arah lepas pantai, yaitu di sekitar Kepulauan Masalembo dan Matasiri.

\section{Parameter Kematian Ikan Layang (Decapterus russelli dan Decapterus macrosoma)}

\section{Di Perairan Natuna}

Kematian total (Z) Decapterus russelli di perairan Natuna dari tahun 2003 sampai dengan 2005 berfluktuasi dan cenderung naik, sedangkan nilai $Z$ untuk Decapterus macrosoma berfluktuasi dan cenderung turun antara 4,8 dan 5,2. Nilai-nilai F tiap tahun untuk ke-2 spesies selalu lebih besar dari masing-masing nilai M. Sementara itu, tingkat eksploitasi (E) Decapterus russelli pada tahun 2005 naik dari 0,65 menjadi 0,67, untuk Decapterus macrosoma turun dari 0,66 menjadi 0,65 (Tabel 4a).

Dengan metode Elefan (Hariati \& Pralampita, 2008) dihasilkan nilai-nilai $Z$ yang sedikit lebih rendah $(4,4$ sampai dengan 4,8 untuk Decapterus russellidan 4,8 sampai dengan 5,1 untuk Decapterus macrosoma), sedangkan nilai-nilai $F$ cenderung lebih tinggi $(1,73$ sampai dengan 1,75), menghasilkan nilai-nilai dugaan E masing-masing 0,61 sampai dengan 0,64 (Decapterus russelli) dan 0,64 sampai dengan 0,65 (Decapterus macrosoma), mendekati nilai-nilai dugaan $\mathrm{E}$ dari tulisan ini.

\section{Di Perairan Anambas}

Dalam Tabel 4b, di perairan Anambas nilai-nilai dugaan Z Decapterus russelli naik dari 3.5 menjadi 3,8 , juga nilai $E(0,52$ sampai dengan 0,54$)$. Nilainilai Z dari Decapterus macrosoma tiap tahun meningkat dari 4,2 sampai dengan 4,5, juga nilai $E$ (0,60 sampai dengan 0,62$)$. Tingkat eksploitasi (E) ke-2 spesies ikan layang (Decapterus russelli dan Decapterus macrosoma) di ke-2 perairan Laut Cina Selatan Indonesia hasil analisis tersebut cenderung tinggi, dengan nilai-nilai F (kematian karena penangkapan) yang selalu lebih tinggi daripada nilai $\mathrm{M}$ (kematian alami).

Tabel 4a. Nilai-nilai dugaan parameter kematian ikan layang (Decapterus russelli dan Decapterus macrosoma) dari perairan Natuna, tahun 2003 sampai dengan 2005

Table 4a. $\quad$ Estimated values of mortality parameters of scads (Decapterus russelli and Decapterus macrosoma) from the waters aroud Natuna Island, years 2003 to 2005

\begin{tabular}{cccccccccc}
\hline $\begin{array}{c}\text { Decapterus } \\
\text { russelli }\end{array}$ & $\mathbf{Z}$ & $\mathbf{M}$ & $\mathbf{F}$ & $\mathbf{E}$ & $\begin{array}{c}\text { Decapterus } \\
\text { macrosoma }\end{array}$ & $\mathbf{Z}$ & $\mathbf{M}$ & $\mathbf{F}$ & $\mathbf{E}$ \\
\hline 2003 & 4,92 & 1,71 & 3,21 & 0,65 & 2003 & 5,10 & 1,71 & 3,39 & 0,66 \\
2004 & 4,84 & 1,70 & 3,14 & 0,65 & 2004 & 4,94 & 1,67 & 3,27 & 0,66 \\
2005 & 5,16 & 1,71 & 3,45 & 0,67 & 2005 & 4,89 & 1,71 & 3,18 & 0,65 \\
\hline
\end{tabular}

Tabel 4b. Nilai-nilai dugaan parameter kematian ikan layang (Decapterus russelli dan Decapterus macrosoma) di perairan Anambas, tahun 2003 to 2005

Table $4 b$. Estimated values of mortality parameters of scads (Decapterus russelli and Decapterus macrosoma) from the waters around Anambas Islands, years 2003 to 2005

\begin{tabular}{cccccccccc}
\hline $\begin{array}{c}\text { Decapterus } \\
\text { russelli }\end{array}$ & $\mathbf{Z}$ & $\mathbf{M}$ & $\mathbf{F}$ & $\mathbf{E}$ & $\begin{array}{c}\text { Decapterus } \\
\text { macrosoma }\end{array}$ & $\mathbf{Z}$ & $\mathbf{M}$ & $\mathbf{F}$ & $\mathbf{E}$ \\
\hline 2003 & 3,53 & 1,69 & 1,84 & 0,52 & 2003 & 4,24 & 1,69 & 2,55 & 0,60 \\
2004 & 3,70 & 1,69 & 2,01 & 0,54 & 2004 & 4,50 & 1,69 & 2,81 & 0,62 \\
2005 & 3,75 & 1,72 & 2,03 & 0,54 & 2005 & 4,51 & 1,72 & 2,79 & 0,62 \\
\hline
\end{tabular}


Dengan metode Elefan, nilai-nilai dugaan Z untuk Decapterus russelli dan Decapterus macrosoma berkisar antara 3,9 dan 4,2 (Hariati \& Pralampita, 2008). Nilai-nilai dugaan E untuk Decapterus russelli dan Decapterus macrosoma hasil dari analisis Elefan berkisar antara 0,56 sampai dengan 0,57. Dengan metode yang digunakan dalam tulisan ini (model progression analysis), nilai-nilai $\mathrm{E}$ yang diperoleh untuk Decapterus russelli cenderung lebih rendah, sedangkan untuk Decapterus macrosoma lebih tinggi dari nilai-nilai E hasil analisis dengan Elefan.

Pada tahun 1998 Atmadja (2005) memperoleh nilainilai dugaan $E$ yang rendah yaitu 0,31 untuk Decapterus russelli dan 0,39 untuk Decapterus macrosoma. Di perairan Manila pada periode yang sama (tahun 2003 sampai dengan 2005), Ramiscal (2007) memperoleh nilai E untuk Decapterus russelli yang jauh lebih rendah, dari hasil penelitian ini, yaitu 0,44 .

Di perairan Sabah dalam periode tahun 2005, tingkat eksploitasi Decapterus macrosoma berkisar antara 0,5 sampai dengan 0,7 (Sade \& Isnain, 2006), sedangkan di Semenanjung Malaysia bagian timur (Kuantan, Laut Cina Selatan) tingkat eksploitasi mencapai 0,7 (Basir, 2007). Dibandingkan dengan tingkat eksploitasi di perairan Sabah dan Semenanjung Malaysia yang juga merupakan bagian dari Laut Cina Selatan, nilai dugaan tingkat eksploitasi ikan layang (Decapterus russelli dan Decapterus macrosoma) hampir mendekati nilai $\mathrm{E}$ dari penelitian ini.

Pada akhir tahun 2005, terjadi penurunan jumlah kapal yang aktif sebagai dampak naik harga bahan bakar untuk perusahaan, antara lain di Pekalongan 41 unit (dari 140 menjadi 99 unit) dari tahun 2004 dan di Pemangkat 14 unit dari tahun 2004 dari 48 menjadi 36 unit), bahkan di tempat-tempat pendaratan kapal pukat cincin lain juga turun, secara total sekitar 25\% Diharapkan dengan penurunan jumlah upaya tersebut, nilai E di perairan Natuna pada tahun 2006 turun sekitar 25\% dari tahun 2005. Dengan demikian, dapat disarankan agar tidak dilakukan penambahan jumlah kapal yang diizinkan untuk beroperasi di ke-2 perairan Laut Cina Selatan.

\section{KESIMPULAN DAN SARAN}

\section{Kesimpulan}

Tingkat pemanfaatan (E) ikan layang (Decapterus russelli dan Decapterus macrosoma) di Laut Cina Selatan sudah tinggi, untuk Decapterus russelli antara
0,63 dan 0,67, untuk Decapterus macrosoma antara 0,72 dan 0,75 .

\section{Saran}

Sebagai saran, sebaiknya tidak dilakukan penambahan jumlah kapal yang diizinkan untuk beroperasi di ke-2 perairan Laut Cina Selatan.

\section{PERSANTUNAN}

Kegiatan dari hasil riset pengkajian stok ikan pelagis kecil di perairan Laut Cina Selatan, T.A. 2005, di SEAFDEC.

\section{DAFTAR PUSTAKA}

Atmadja, S. B. 1988. Estimation of growth and mortality of round scad (Decapterus macrosoma) in the Java Sea, Indonesia. Contribution to Tropical Fisheries Biology. Edited by S. Venema, J. M. Christensen, \& D. Pauly. FAO Fish. Rep. 389. Rome. p. 324-345.

Badrudin, M. 1986. The small pelagic stock abundance in the surrounding waters of Anambas and Natuna Islands group of the Riau Province. Jurnal Penelitian Perikanan Laut. No.36. p.39-48.

Basir, S. 2007. National country report for Peninsular Malaysia. Information Collection for Sustainable Pelagic Fisheries in the South China Sea. p. 113196.

Choliq, F., M. F. Sukadi, S. Nurhakim, I. G. S. Merta, \& J. Widodo. 1995. Evaluasi pengkajian sumber daya perikanan laut. Pusat Penelitian dan Pengembangan Perikanan. Badan Penelitian dan Pengembangan Pertanian. 15 hal.

Gayanilo Jr., F. C. \& D. Pauly. 1997. FiSAT. Reference manual. ICLARM. FAO. 262p.

Hariati, T. \& W. A. Pralampita. 2008. Analisis frekuensi panjang ikan layang (Decapterus russelli dan Decapterus macrosoma) di perairan Laut Cina Selatan. Prosiding Seminar Nasional Tahunan. 26 Juni 2008. Hasil Penelitian Perikanan dan Kelautan 2008. Jilid 2. Manajemen Sumber Daya Perikanan. Kode MS07. 9 hal.

Mat Isa, M., S. Siriraksophon, R. Rumpet, S. A. S. A. Kadir, S. Ishikawa, \& M. Supongpan. 2004. Standard operating procedures for data collection and analysis in the South China Sea. SEAFDEC. $47 \mathrm{p}$. 
Ramiscal, R. V., R. O.Romero, \& D. D. Tanay. 2007. National country report for the Philippines. Information Collection for Sustainable Pelagic Fisheries in the South China Sea Information Collection for Sustainable Pelagic Fisheries in the South China Sea. p. 228-304.

Sade, A. \& I. Isnain. 2007. National country report for Information collection for sustainable pelagic fisheries in the South China Sea. Final report for Sabah, East Malaysia. Country Report. Fishery and Sabah. Information Collection for Sustainable Pelagic Fisheries in the South China Sea Information Collection for Sustainable Pelagic Fisheries in the South China Sea. p. 136-196.

Sadhotomo, B. \& M. Potier. 1995. Explotation of the large and medium seiners fisheries. In Biodynex of the small pelagic fisheries in the Java Sea.
Scientific Editors M. Poties \& S. Nurhakim. P. 195214.

Sparre, P. \& S. C. Venema. 1999. Introduksi pengkajian stok ikan tropis. Buku I. Manual. FAOUNO. 438 hal.

South China Sea. 1979. Report of workshop on demersal and pelagisc fish in Java Sea. SEAFDEC-South China Sea (Gen/79/20). 19 p.

Widodo. J. 1988. Population biology of Russell's Scad (Decapterus russelli) in the Java Sea, Indonesia. Contribution to Tropical Fisheries Biology. Edited by S. Venema, J. M. Christensen, \& D. Pauly FAO Fishery Report 389. Rome. p. 308-323.

Wyrtki, K. 1961. Physical oceanography of the Southeast Asia water. Naga. Report. 2. 195 p. 